Bangladesh J. Plant Taxon. 26(1): 47-55, 2019 (June)

(C) 2019 Bangladesh Association of Plant Taxonomists

\title{
POLLEN MORPHOLOGICAL STUDY ON SOME RARE ALLIUM L. (AMARYLLIDACEAE) TAXA IN TURKEY
}

\author{
Birol Başer, Mehmet Firat ${ }^{1}$ and Riza BinZet ${ }^{2 *}$ \\ Department of Biology, Faculty of Arts and Science, Bitlis Eren University, Bitlis/Turkey
}

Keywords: Allium; Amaryllidaceae; Micromorphology; Pollen morphology; LM; SEM; Turkey.

\begin{abstract}
The pollen morphology of 10 Allium L. taxa, 6 of which are endemic to Turkey, were investigated in detail by light and scanning electron microscopy. According to LM and SEM, the pollen grains of genera were monad, monosulcate percolate, heteropolar with bilateral symmetry, 25.30 to $53,85 \mu \mathrm{m}$ long axis (LA) and 17.55 to $36.86 \mu \mathrm{m}$ short axis (SA), the form was prolate (mean of LA/SA ratio 1.30 to 1.70 and in polar view boat-shaped. Three types of ornamentation were determined. Striate-rugulate-perforate type in Allium longisepalum, A. oreophilum, A. anacoleum, A. microspathum, A. shirnakiense, $A$. purpureoviride and $A$. armenum, Rugulate-perforate type in $A$. pervariense and $A$. gabardagense and Rugulate-reticulate-perforate type in $A$. arlgirdense. Sulcus membrane ornamentations were rugulate or psilate. The sulcus extends from the distal to proximal ends in A. anacoleum, A. arlgirdense and $A$. pervariense. The present study on some Turkish species of Allium showed that several morphological pollen characters may possess taxonomical value.
\end{abstract}

\section{Introduction}

The Allium L. genus was formerly included in the Liliaceae family, but the Angiosperm Phylogeny Group (APG) reassessed the taxonomic position of this genus and finally Allium was placed in the Amaryllidaceae family (APG III 2009). The genus Allium comprises more than 850 species, making it one of the largest petaloid monocotyledonous genera (Fritsch et al., 2010; Keusgen et al., 2011; Herden et al., 2016). It is a variable group that is widely spread across the Holoarctic region from the dry subtropics to the boreal zone ( $\mathrm{Li}$ et al., 2010). Turkey has approximately 200 Allium taxa in 14 sections, c. one-third of which are endemic to this territory, demonstrating that Turkey is a prominent part of the southeastern Asian center of Allium diversity (Koyuncu 2012; Eksi et al., 2015; 2016; Firat 2015; 2017; Firat et al., 2018). Turkey is very rich in terms of biodiversity. The main reasons are: i) It is the meeting point of three phytogeographical regions. ii) Asian part of Turkey is a passageway and a migration route between Southern Europe and the flora of South-West Asia allowing the penetration of Asiatic elements into South Europe. iii) Many taxa have their center of origin and/or center of diversity in Anatolia. iv) The high endemism ratio, presumably connected with the climatic and topographical diversity of the country (Davis, 1965, 1971).

The family Amaryllidaceae is more or less stenopalynous taxon and pollen grains are generally monocolpate, bilateral symmetrical, boat shaped with subpsilate or rugulate-foveolate rarely reticulate tectum (Erdtman, 1952). Data on pollen morphology of representatives of Allium genus as acquired under LM microscope were given by Nair and Sharma (1965), Radulescu (1973), Diez (1987) and El-Sadek et al., (1994). In recent years, several researchers have

\footnotetext{
*Corresponding author, Email: rbinzet@gmail.com, rbinzet@mersin.edu.tr

${ }^{1}$ Department of Biology, Faculty of Education, Yüzüncü Y1l University, Van/Turkey.

${ }^{2}$ Department of Biology, Faculty of Arts and Science, Mersin University, 33343, Mersin, Turkey.
} 
investigated this area, their studies have focused on some selected, constantly very rare species representing Guler and Pehlivan (2006), Namin et al. (2009), Neshati et al. (2009), Ozhatay and Kocyigit (2009), Ozler and Pehlivan (2010) and Maassoumi et al. (2014).

Pollen morphoplogy of the Allium species, which is the most difficult Monocotyledon family from systematic and taxonomic point of view (Guler and Pehlivan, 2006). In order to solve these problems, detailed pollen morphological studies of 10 species of the genus Allium have been investigated. Further attempts should additionally be undertaken to rate whether earlier not recognized pollen characters may be useful taxonomic markers at infrageneric or even species level in Allium.

\section{Materials and Methods}

\section{Pollen sampling}

Pollen samples were taken from specimens deposited in Herbarium of Van, Yüzüncü Yıl University (VANF). The complete list of the investigated taxa with sample provenance is reported in Table 1.

Table 1. List of voucher specimens belonging to the genus Allium.

\begin{tabular}{|c|c|c|c|}
\hline Section & Taxa & Localities & Satus \\
\hline $\begin{array}{l}\text { Molium G. Don ex } \\
\text { W.D.J. Koch }\end{array}$ & $\begin{array}{l}\text { Allium } \\
\text { longisepalum } \\
\text { Bertol. }\end{array}$ & $\begin{array}{l}\text { Turkey. Şırnak, Gabar Mountain, open oak forest, } \\
700 \text { m, } 2 \text { May 2014, M. Firat } 30635\end{array}$ & Rare \\
\hline $\begin{array}{l}\text { Porphyroprason } \\
\text { Ekberg. }\end{array}$ & $\begin{array}{l}\text { A. oreophilum } \\
\text { C.A. Meyer, } \\
\text { Verz. }\end{array}$ & $\begin{array}{l}\text { Turkey. B9 Van, Başkale discrict, İspiriz mountain, } \\
\text { Rocky places, scree, } 3300 \text { m, } 7 \text { June 2014, M. Firat } \\
31010\end{array}$ & Rare \\
\hline \multirow[t]{3}{*}{ Scorodon C. Koch } & $\begin{array}{l}\text { A. anacoleum } \\
\text { Hand.-Mazz. }\end{array}$ & $\begin{array}{l}\text { Turkey. Hakkari, Sat Mountain, rocky region, } 2900 \\
\text { m, } 8 \text { August 2014, M. Firat } 30987\end{array}$ & Rare \\
\hline & $\begin{array}{l}\text { A. microspathum } \\
\text { Ekberg }\end{array}$ & $\begin{array}{l}\text { Turkey. Hakkari, Sat Mountain, rocky region, } 2900 \\
\text { m, } 8 \text { August 2014, M. Firat } 30985\end{array}$ & Endemic \\
\hline & $\begin{array}{l}\text { A. arlgirdense } \\
\text { Blakelock }\end{array}$ & $\begin{array}{l}\text { Turkey. Hakkari, Sat Mountain, rocky region, } 2900 \\
\text { m, } 8 \text { August 2014, M. Firat } 30986\end{array}$ & Rare \\
\hline $\begin{array}{l}\text { Codonoprasum } \\
\text { Reichb. }\end{array}$ & $\begin{array}{l}\text { A. armenum } \\
\text { Boiss. \& Kotschy }\end{array}$ & $\begin{array}{l}\text { Turkey. B9 Van, Bahçesaray discrict, Agirov } \\
\text { mountain, Rocky places, } 2400 \text { m, } 1 \text { July 2015, M. } \\
\text { Firat } 31010\end{array}$ & Endemic \\
\hline \multirow[t]{2}{*}{$\begin{array}{l}\text { Melanocrommyum } \\
\text { Webb \& Berth. }\end{array}$} & $\begin{array}{l}\text { A. shirnakiense L. } \\
\text { Behçet \& } \\
\text { Rüstemoğlu }\end{array}$ & $\begin{array}{l}\text { Turkey. C9, Şırnak, Beytüşşebap district, Cevam } \\
\text { region, rocky area, } 1450 \text { m, } 30 \text { May 2014, M. Firat } \\
30843\end{array}$ & Endemic \\
\hline & $\begin{array}{l}\text { A. purpureoviride } \\
\text { M. Koyuncu \& İ. } \\
\text { Genç }\end{array}$ & $\begin{array}{l}\text { Turkey. B7 Elazığg, from Elazı ğ to Pertek } 22 \text { km, } \\
\text { near field, } 669 \text { m, } 13 \text { May } 2015 \text { M. Firat } 32691\end{array}$ & Endemic \\
\hline \multirow[t]{2}{*}{ Allium Boiss. } & $\begin{array}{l}\text { A. pervariense } \\
\text { Firat \& Koyuncu }\end{array}$ & $\begin{array}{l}\text { Turkey. C9 Siirt: Pervari, Botan River, opposite to } \\
\text { Bedar (Beğendik) Village, fields converted from } \\
\text { the Quercus forests, 1500-1700 m, } 4 \text { July 2012. M. } \\
\text { Firat } 29712 \text { (AEF 26722). }\end{array}$ & Endemic \\
\hline & $\begin{array}{l}\text { A. gabardagense } \\
\text { Firat }\end{array}$ & $\begin{array}{l}\text { Turkey. C9 Şırnak: Cizre, Gabar mountain slopes, } \\
410 \text { m, limestone rocks, } 01 \text { May 2014, M. Fırat. } \\
\text { 30515) }\end{array}$ & Endemic \\
\hline
\end{tabular}




\section{For LM studies}

Samples were taken from herbarium specimens. For pollen morphological analysis, pollen grains were prepared according to the methods of Wodehouse (1935). The following parameters, as which pollen size i.e. long axis (LA) and short axis (SA), sulcus width, exine thickness and intine thickness were measured. In each sample, 30 pollen grains were measured in order to obtain the maximum and average value of the size. Photomicrographs were made with a Olympus BX31 binocular light microscope.

\section{For SEM studies}

For SEM study, pollen grains obtained from each specimen were transferred onto stubs and coated with platinum. The SEM micrographs were taken with a ZEISS supra 55. The terminologies for pollen morphology were used in accordance with Kosenko (1991a,b) and Hesse et al., (2009).

\section{Results and Discussion}

Pollen morphology of 10 taxa of Allium was investigated by LM (Fig. 1) and SEM (Figs 2-3). The following characters were emphasized as important for separating taxa at different taxonomic value: the sulcus, presence or absence of perforations on the pollen surface, size of perforations, size of the pollen grains and the sulcus extends from distal to proximal end. Present pollen data is based on 10 species of the genus Allium representing 6 sections: Sect. Molium; A. longisepalum. Sect. Porphyroprason; A. oreophilum. Sect. Scorodon; A. anacoleum, A. microspathum, A. arlgirdense. Sect. Codonoprasum; A. armenum. Sect. Melanocrommyum; A. shirnakiense, A. purpureoviride. Sect. Allium; A. pervariense, A. gabardagense. The monosulcate pollen grains, which are regarded as primitive among seed plants, occur widely among the monocotyledons (Ozler and Pehlivan, 2007; Ozhatay and Kocyigit, 2009; Frrat, 2015; 2017; Frrat et al. 2018). The common characteristics of pollen grains were monads, monosulcate, ellipsoidal, and heteropolar in Allium genus. In this study the exine ornamentational characteristics observed in their SEM micrographs were perforate-striate, perforate-rugulate and perforate-striate-rugulate. These results show that there were several pollen characters of taxonomic significance in Allium.

In this study, microperforations visible only on SEM microgaphs. The number of perforation in $1 \mu \mathrm{m}^{2}$ is $2-12$, the diameter of perforation in average is $0.10-0.42 \mu \mathrm{m}$ and the thicknes of lira in average is $0.20-0.60 \mu \mathrm{m}$ (Fig. 3). The diameter of perforation was observed to be the biggest in $A$. microspathum (Fig. 3; 4). The number of perforations in $1 \mu \mathrm{m}^{2}$ was more in A. armenum (Fig. 3; 6). Intine $1.05-0.40 \mu \mathrm{m}$ thick. The A. longisepalum had thicknest intine while A. microspathum had thinnest one (Table 2).

Some researchers have showed that the sulcus features and the presence of operculum may be a taxonomic value in some families (Chanda et al., 1979; Kosenko, 1991a,b; Güler and Pehlivan, 2006; Ozler and Pehlivan, 2010). In SEM photomicrographs, sulcus membranes are psilate in $A$. pervariense, A. oreophillum, A. arlgirdense, A. armenum and A. shirnakense. Rugulate sulcus membrane ornamentation was found in A. microsepalum, A. anacoleum, A. longisepalum, A. gabardagense and A. purpureoviride (Fig. 3). The operculum was found to be fragmented on the sulcus membrane (Fig 1; 10). Similarly, Guler and Pehlivan (2006), Ozler and Pehlivan (2010) reported that sulcus membrane ornamentations were psilate, psilate-perforate and rugulateperforate in Allium taxa and the operculum was found to be fragmented on the sulcus membrane or sometimes completely covering it.

The common characteristics of the pollen grains of Allium have been investigated. Species showed that their pollen apertures are monosulcate and monosulcate-operculate. The advantage of 
a monosulcate aperture (extended sulcate) in monocotyledons with the inclusion of Allium, is underlined by Harley and Zavada (2000) and Ozler and Pehlivan (2010). In the present study, biggest pollen size was found in A. longisepalum, whereas the smallest was found in $A$. arlgirdense (Table 2). It was recognized that the sulcus extends from distal to proximal end in $A$. anacoleum, A. arlgirdense and A. pervariense investigated. The width of the sulcus ranged from $2.75-5.77 \mu \mathrm{m}$ (Table 2). The extended sulcus type has been observed on Allium and the family
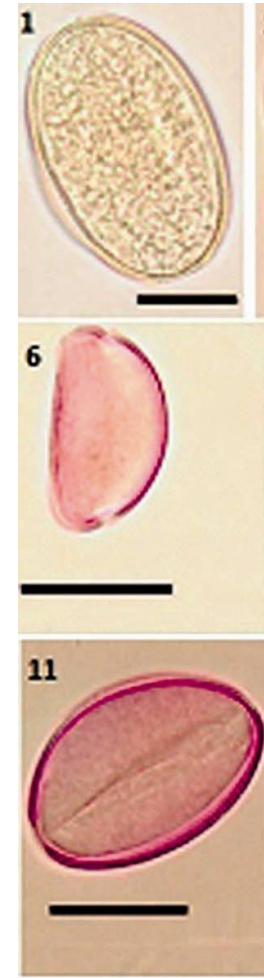

16

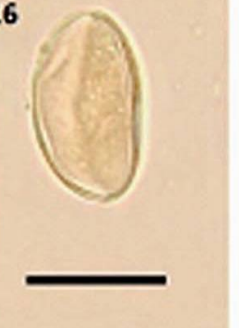

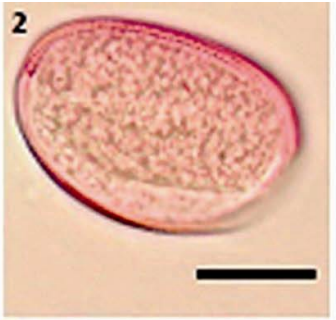

7

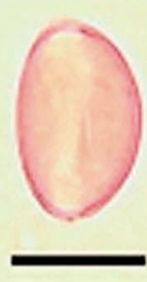

12

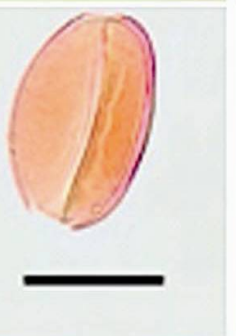

17

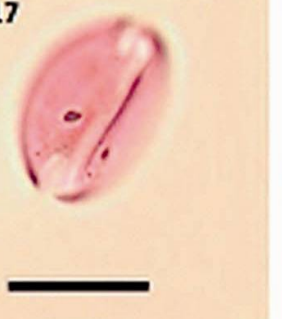

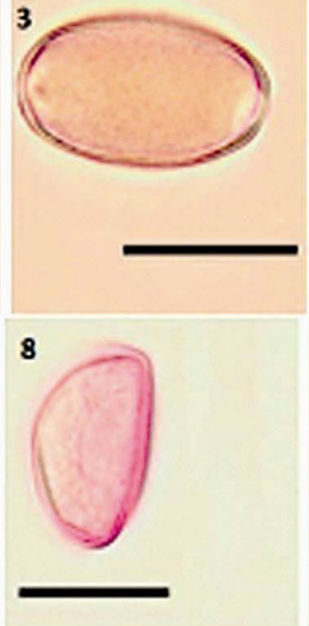

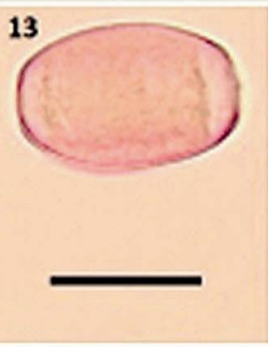

18

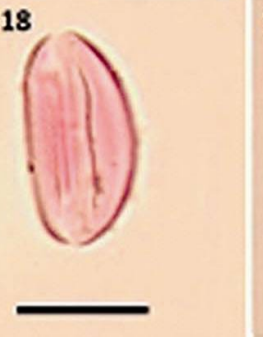

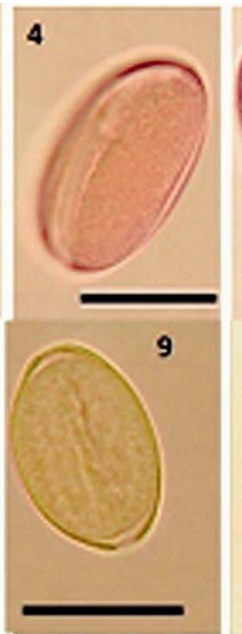

14
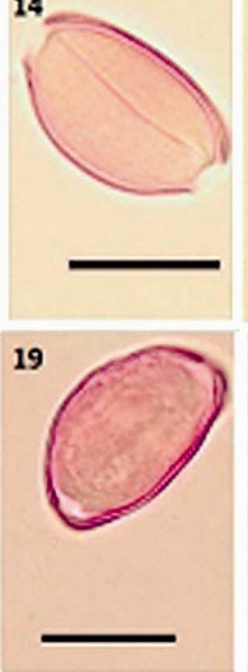

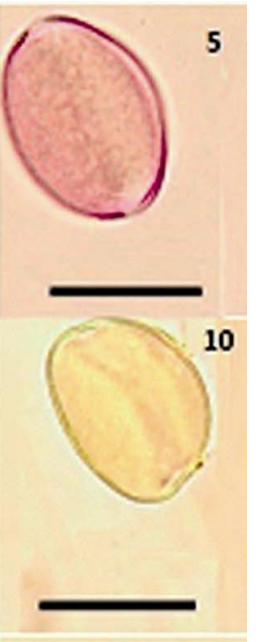

15

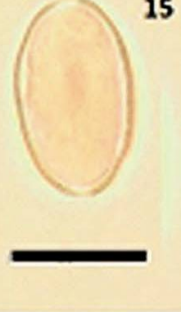

20

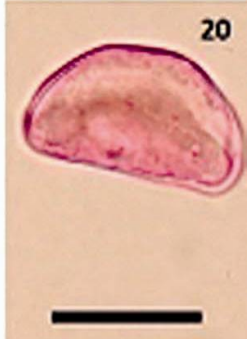

Fig. 1. LM microphotography of examined Allium pollen.1-2: A. longisepalum, 3-4: A. oreophilum, 5-6: A. anacoleum, 7-8: A. microspathum, 9-10: A. arlgirdense, 11-12: A. armenum 13-14: A. shirnakiense, 15-16: A. purpureoviride, 17-18: A. pervariense, 19-20: A. gabardagense (scale $20 \mu \mathrm{m}$ ).

Liliaceae (Guler and Pehlivan, 2006; Ozler and Pehlivan, 2007; 2010). The sulcus ends were sharp in A. arlgirdense, A. anacoleum, A. armenum and A. gabardagense (Fig. 2; 6, 10, 12, 20). The sulcus ends were rounded in the other investigated taxa (Fig. 2; 4, 8, 14, 16, 18). The longest 
sulcus extension dimension was measured in A. pervariense, whereas the shortest dimension was observed in A. arlgirdense (Table 2). The widest sulcus dimension was seen in A. pervariense. The longest length dimension of sulcus was seen in A. longisepalum and the shortest dimension was seen in A. arlgirdense (Table 2). The thickest exine dimension was found in A. longisepalum and the thinnest exine dimension was found in A. shirnakiense (Table 2). According to SEM, the exine sculpturing was striate-perforate, striate-rugulate-perforate and rugulate-perforate (Table 2, Fig 2, 1-19). Perforate-striate, perforate-rugulate and perforate-striate-rugulate exine structure have been reported in previous investigations (Guler and Pehlivan, 2006; Ozler and Pehlivan, $2007 ; 2010)$.

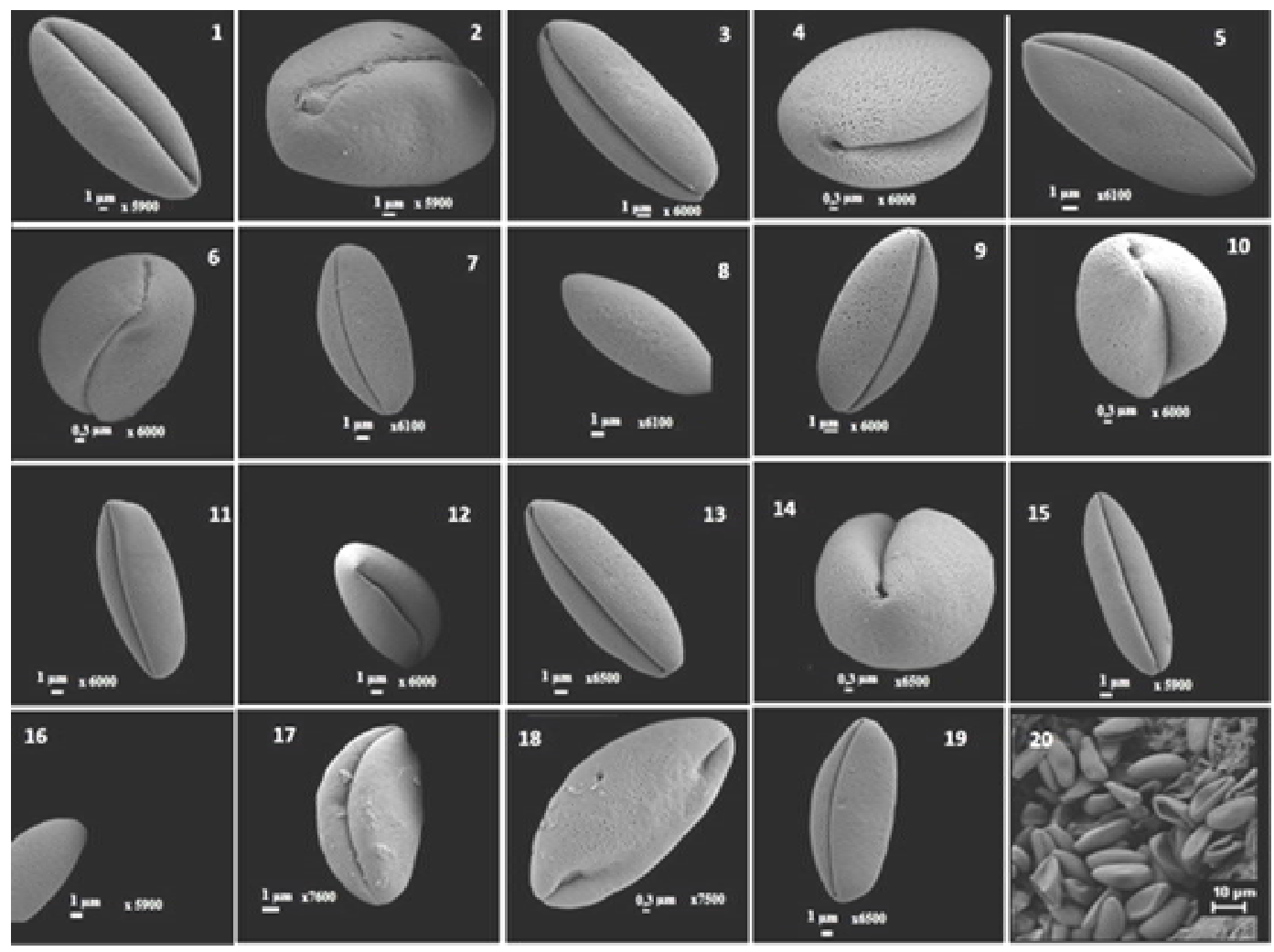

Fig. 2. SEM microphotography of the examines Allium pollen.1-2: A. longisepalum,3-4: A. oreophilum, 5-6: A. anacoleum, 7-8: A. microspathum, 9-10: A. arlgirdense, 11-12: A. armenum, 13-14: A. shirnakiense, 15-16: A. purpureoviride, 17-18: A. pervariense, 19-20: A. gabardagense.

Allium taxa are of three types ornamentational characteristics as follows; Striate-rugulateperforate: A. longisepalum, A. oreophilum, A. anacoleum, A. microspathum, A. shirnakiense, A. purpureoviride and A. armenum; Rugulate-perforate: A. pervariense, A. gabardagense; Rugulatereticulate-perforate: $A$. arlgirdense.

The main palynological differences have been registered at the section level. These results are similar to the earlier studies (Guler and Pehlivan, 2006; Ozler and Pehlivan, 2007; 2010; Neshati et al., 2009; Ozhatay and Kocyigit, 2009). 


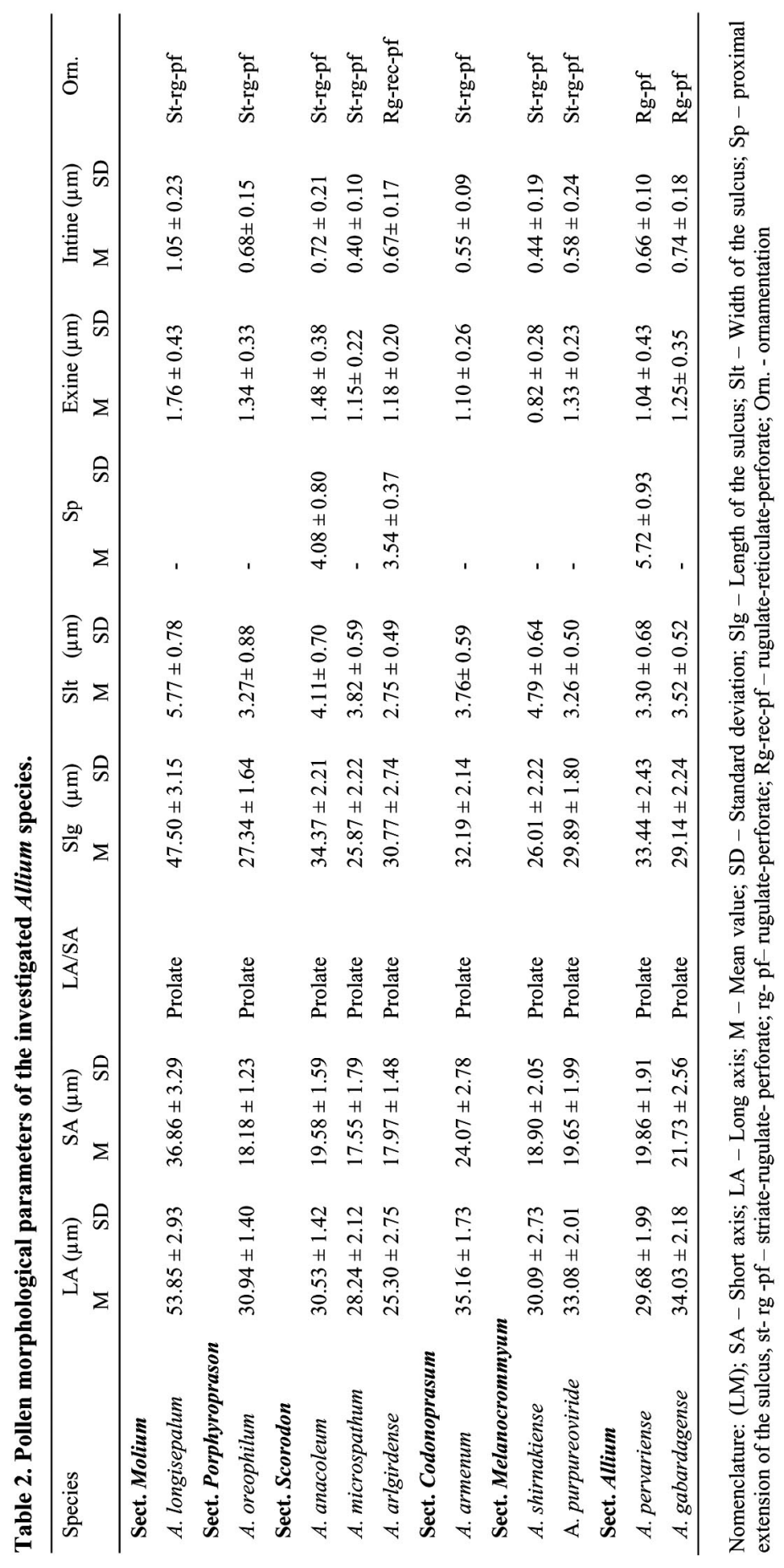



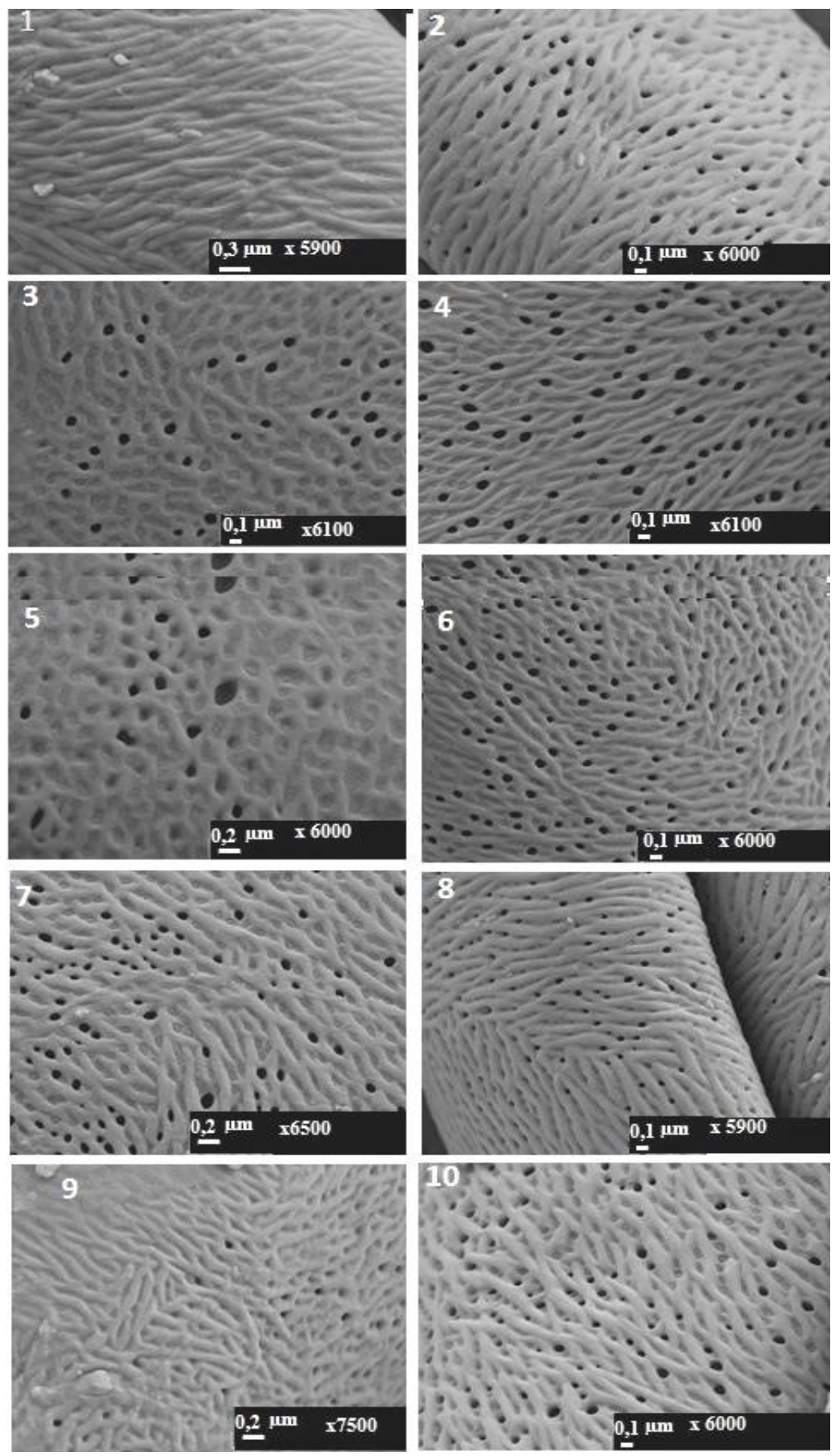

Fig. 3. SEM microphotography of the pollen ornamentation: 1. A. longisepalum; 2. A. oreophilum; 3. A. anacoleum; 4. A. microspathum; 5. A. arlgirdense; 6. A. armenum; 7. A. shirnakiense; 8. A. purpureoviride; 9. A. pervariense; 10. A. gabardagense. 


\section{Acknowledgements}

This academic work was linguistically supported by the Mersin Technology Transfer Office Academic Writing Center of Mersin University.

\section{References}

APG III. 2009. An update of the angiosperm phylogeny group classification for the orders andfamilies of flowering plants: Bot. J. Linn. Soc. 161: 105-121. doi: 10.1111/j.1095-8339.2009.00996.x

Chanda, S., Ghosh, K. and Nilsson, S. 1979. On the polarity and tetrad arrangements in some mono and diaperturate angiosperm pollen grains. Grana 18: 21-31.

Davis P.H., (ed.). 1965. Flora of Turkey and the East Aegean Islands. Vol. 1. Edinburgh: Edinburgh University Press. Edinburgh, 567 pp.

Davis P.H., (ed.). 1971. Distribution patterns in Anatolia with particular reference to endemism. In: Davis PH, Harper PC, Hedge IC, editors. Plant life of South-West Asia. Edinburgh: The Botanical Society of Edinburgh. pp. 15-27.

Diez, M.J. 1987. Liliaceae. In: Atlas polinico de Andalucia, Valdes, B., Diez, M.J., Fernandez, I. (eds). Occidental Instituto de Desarrollo Regional Universidad de Sevilla y Excma Diputacion de Cadiz Sevilla, pp. 379-395.

Eksi, G., Koyuncu, M. and Bona, M. 2015. Allium phanerantherum subsp. involucratum (Amaryllidaceae), a new species from Turkey. Bangl. J. Plant Taxon. 22: 143-146.

Eksi, G., Koyuncu, M. and Özkan, A.M.G. 2016. Allium ekimianum: A new species (Amaryllidaceae) from Turkey. PhytoKeys 62: 83-93.

El-Sadek, L., El-Gazaly, G. and Ayvad, M. 1994. Cytology and palynology of common monocots in Mariut Egypt 1. Common species of the families Alliaceae and Liliaceae. Quatar Univ. Si. J. 14(2): 270-280.

Erdtman, G. 1952. Pollen morphology and plant taxonomy, Angiosperms. Almquist and Wiksell., Stockholm.

Fırat, M. 2015. Allium gabardaghense (Amaryllidaceae), a new species from Şırnak, Turkey. Van: Weşanên Sîtav.

Firat, M. 2017. Allium hoshabicum a new species of A. sect. Codonoprasum (Amaryllidaceae) from Van (Turkey), Phytotaxa 312: 129-134

Fırat, M., Koyuncu, M. and Ekşi, G. 2018. Allium pervariensis, sect. Allium (Amaryllidaceae), a new species from Siirt Turkey, Plant Biosystems - An International Journal Dealing with all Aspects of Plant Biology, 152: 305-310.

Fritsch, R.M., Blattner, F.R. and Gurushidze, M. 2010. New classification of Allium L. subg. Melanocrommyum (Webb \& Berthel.) Rouy (Alliaceae) based on molecular and morphological characters. Phyton 49: 145-220.

Guler, U. and Pehlivan, S. 2006. Pollen morphology of some species belonging to Codonoprasum and Allium sections of Allium L. (Liliaceae-Alliaceae) genus. Biologia (Bratisl) 61: 449-455.

Harley, M.M. and Zavada, M.S. 2000. Pollen of the monocotyledons: Selecting characters for cladistic analysis. In: Monocots: Systematics and Evolution, K.L. Wilson and D.A Morrison (Eds), CSIRO, Melbourne. pp. 194-213.

Herden, T. Hanelt, P. and Friesen, N. 2016. Phylogeny of Allium L. subgenus Anguinum (G. Don. ex W.D.J. Koch) N. Friesen (Amaryllidaceae). Mol. Phylogenet. Evol. 95: 79-93.

Hesse, M., Halbritter, H., Zetter, R., Weber, M., Buchner, R., Frosch-Radivo, A. and Ulrich, S. 2009. Pollen terminology. An illustrated handbook. Springer, Vienna.

Keusgen, M., Kusterer, J. and Fritsch, R.M. 2011. Allium species from Middle and Southwest Asia are a rich source for Marasmin. J Agric Food Chem. 59: 8289-8297.

Kosenko, V.N. 1991a. Pollen morphology of the genus Fritillaria (Liliaceae). Bot. Zh. 76: 1696-1706.

Kosenko, V.N. 1991b. Pollen morphology of the family Liliaceae s. str. Bot. Zh. 76: 1201-1210. 
Koyuncu, M. 2012. Allium L. In: Güner A, Aslan S, Ekim T, Vural M, Babaç MT, editors. Türkiye Bitkileri Listesi (Damarlı Bitkiler). İstanbul: Nezahat Gökyiğit Botanik Bahçesi ve Flora Araştırmaları Derneği Yayın1. pp. 30-44.

Li, Q.Q., Zhou S.D., He X.J., Yu, Y., Zhang Y.C. and Wei, X.Q. 2010. Phylogeny and biogeography of Allium (Amaryllidaceae: Allieae) based on nuclear ribosomal internal transcribed spacer and chloroplast rps 16 sequences, focusing on the inclusion of species endemic to China. Ann. Bot. 106: 709-733.

Maassoumi, S.M., Kiani, S., Bareemizadeh, F., Ghasempour, H., Karimi, N., Shohani, F. and Amiri, S. 2014. Pollen morphology of the genus Allium in comparison with genus Calochortus of order Liliales. Int. J. Biosci. 4(12): 237-243.

Nair, P.K.K. and Sharma, M. 1965. Pollen morphology of Liliaceae. J. Palynol. 1: 38-61.

Namin, H.H., Mehrvarz, S.S., Zarre, S. and Fritsch, R. 2009. Pollen morphology of selected species of Allium (Alliaceae) distributed in Iran. Nord. J. Bot. 27(1): 54-60.

Neshati, F., Fritsch, R.M. and Zarre, S. 2009. Pollen morphology of some Allium L. species (Alliaceae) from Iran. Bot. Jahrb. Syst. 127(4): 433-451.

Ozhatay, N. and Koçyigit, M. 2009. Pollen morphology of Allium species (Lilliaceae) in European Turkey and around Istanbul. Phytol. Balc. 15(2): 199-208.

Ozler, H. and Pehlivan, S. 2007. Comparison of Pollen morphological structures of some taxa belonging to Asparagus L. and Fritillaria L. (Liliaceae) From Turkey. Bangladesh J Bot. 36(2): 111-120.

Ozler, H. and Pehlivan, S. 2010. Pollen morphology of Allium L. (Lilliaceae) taxa in Turkey. Bangladesh J Bot. 39(1): 37-46.

Radulescu, D. 1973. Recherches morpho-palynologiques sur la famille Liliaceae. Acta Horti Bot. Bucurest. 193- 248.

Wodehouse, R.P. 1935. Pollen Grains. New York: McGraw Hill Press. 439 pp. 